\title{
Strategies Towards Antigen-Specific Treatments for Membranous Nephropathy
}

\author{
Sarah M. S. Köllner ${ }^{\dagger}$, Larissa Seifert ${ }^{\dagger}$, Gunther Zahner and Nicola M. Tomas * \\ III. Department of Medicine, University Medical Center Hamburg-Eppendorf, Hamburg, Germany
}

Membranous nephropathy ( $\mathrm{MN}$ ) is a rare but potentially severe autoimmune disease and a major cause of nephrotic syndrome in adults. Traditional treatments for patients with MN include steroids with alkylating agents such as cyclophosphamide or calcineurin inhibitors such as cyclosporine, which have an undesirable side effect profile. Newer therapies like rituximab, although superior to cyclosporine in maintaining disease remission, do not only affect pathogenic B or plasma cells, but also inhibit the production of protective antibodies

OPEN ACCESS

Edited by: Federico Alberici,

University of Brescia, Italy

Reviewed by:

Manuel Praga, Complutense University of Madrid, Spain

*Correspondence: Nicola M. Tomas n.tomas@uke.de

${ }^{t}$ These authors have contributed equally to this work and share first authorship

Specialty section: This article was submitted to Autoimmune and Autoinflammatory Disorders, a section of the journal

Frontiers in Immunology

Received: 25 November 2021 Accepted: 10 January 2022 Published: 03 February 2022

Citation: Köllner SMS, Seifert L, Zahner G and Tomas NM (2022) Strategies Towards Antigen-Specific Treatments for Membranous Nephropathy.

Front. Immunol. 13:822508. doi: 10.3389/fimmu.2022.822508 and therefore the ability to fend off foreign organisms and to respond to vaccination. These are undesired effects of general B or plasma cell-targeted treatments. The discovery of several autoantigens in patients with $\mathrm{MN}$ offers the great opportunity for more specific treatment approaches. Indeed, such treatments were recently developed for other autoimmune diseases and tested in different preclinical models, and some are about to jump to clinical practice. As such treatments have enormous potential to enhance specificity, efficacy and compatibility also for $\mathrm{MN}$, we will discuss two promising strategies in this perspective: The elimination of pathogenic antibodies through endogenous degradation systems and the depletion of pathogenic B cells through chimeric autoantibody receptor $T$ cells.

Keywords: membranous nephropathy, antigen-specific antibodies, B cells, chimeric autoantibody receptor, sweeping antibody, autoantibodies

\section{INTRODUCTION}

Membranous nephropathy ( $\mathrm{MN})$ is a rare but potentially severe kidney disease and a major cause of nephrotic syndrome in adults. According to the new KDIGO 2021 Clinical Practice Guidelines, a nephrotic syndrome is defined as proteinuria of more than 3.5 grams per 24 hours or a protein-tocreatinine ratio of more than $3 \mathrm{~g} / \mathrm{g}$ in combination with low plasma albumin, peripheral edema, and hyperlipidemia (1). The descriptive term "membranous" refers to the prominent change that is classically seen in light microscopy: a diffuse thickening of the glomerular basement membrane (2). Additionally, granular depositions of immunoglobulins and complement components can be detected by immunofluorescence microscopy, suggesting a role of both autoantibodies and the complement system in the pathogenesis of MN. The hallmark findings in electron microscopy include electron-dense deposits in a subepithelial localization, i.e. on the outer aspect of the glomerular basement membrane (GBM), and an extensive effacement of podocyte foot processes. 
Due to the prominent glomerular IgG positivity in biopsies of affected patients, $\mathrm{MN}$ has long been assumed to be an antibodymediated autoimmune disease. The discoveries of several target antigens for circulating autoantibodies in $\mathrm{MN}$ patients in the past decade has corroborated this assumption. These targets include neutral endopeptidase (NEP) (3), M-type phospholipase A2 receptor (PLA2R1) (4), thrombospondin type-1 domaincontaining protein 7A (THSD7A) (5), neural epidermal growth factor-like 1 protein (NELL-1) (6), semaphorin 3B (SEMA3B) (7), protocadherin 7 (PCDH7) (8), NCAM1 (9) and HTRA1 (10). PLA2R1-associated $\mathrm{MN}$ is diagnosed in around $70 \%$ of cases and thus represents the most common MN sub-entity.

The current view on the pathogenesis of MN (Figure 1) is that predisposing factors, such as an underlying genetic disposition and/or immune dysregulation, in combination with an initiating trigger such as an infection, a malignancy or environmental factors lead to loss of tolerance for the respective autoantigen with consecutive activation of $\mathrm{B}$ cells and production of autoantibodies (11-18). B cells differentiate towards plasma and/or memory B cells, which in turn produce large amounts of autoantibodies. These autoantibodies reach the kidney via the circulation and bind to their target antigen, which is assumed to induce damage to podocytes with subsequent loss of plasma proteins to the urine, likely via complementdependent and complement-independent mechanisms (19). Complement-independent mechanisms have been ill-defined so far, but may include modification of cellular signaling, antigen/receptor blocking or stimulation or interference with the antigens' biological function, e.g. enzymatic activity. Importantly, the direct pathogenicity of autoantibodies has been demonstrated by transfer experiments of patient-derived anti-NEP and anti-THSD7A autoantibodies, which cause MN in animals $(3,20)$. Even though such a mechanism has not been demonstrated for anti-PLA2R1 autoantibodies, the association of high autoantibody levels with an unfavorable clinical outcome in patients with PLA2R1-associated MN and the development of MN transgenic mice expressing the murine PLA2R1 after transfer of rabbit anti-PLA2R1 antibodies strongly argue for a pathogenic role of anti-PLA2R1 autoantibodies $(21,22)$. Alternative proposed mechanisms of immune deposit formation in $\mathrm{MN}$ include glomerular deposition of preformed immune complexes and binding of circulating antibodies to a planted antigen $(23,24)$, but the relevance of these mechanisms is less clear.

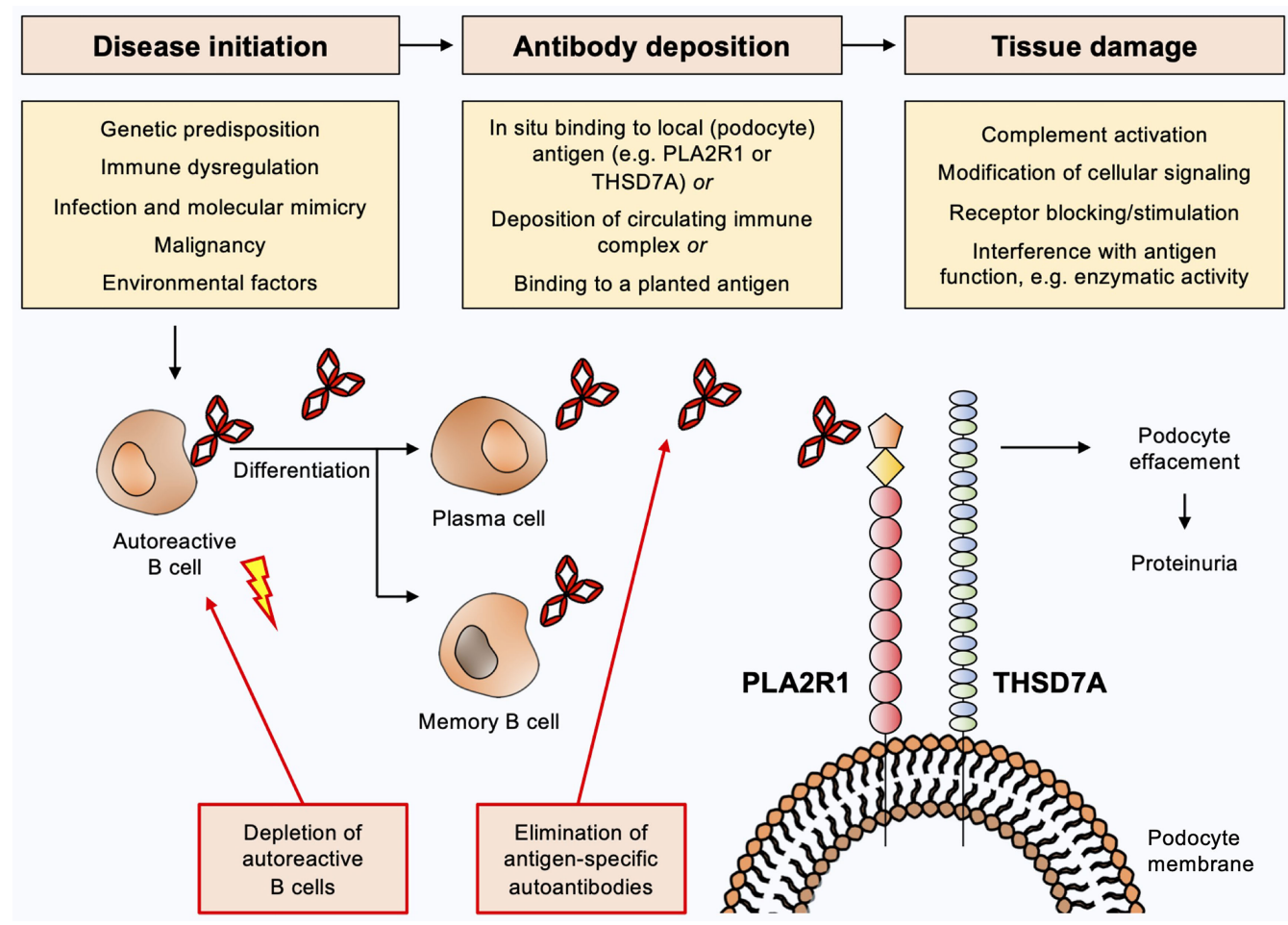

FIGURE 1 | Current view on the pathogenesis of membranous nephropathy and potential targets for antigen-specific treatments. Predisposing factors such as underlying genetic dispositions and/or immune dysregulation in combination with an initiating trigger such as an infection, a malignancy or environmental factors may lead to loss of tolerance for the respective autoantigen with consecutive activation of B cells and production of autoantibodies. B cells differentiate to plasma and/or memory B cells, which in turn produce large amounts of autoantibodies. These autoantibodies reach the kidney via the circulation and bind to their target antigen (e.g. PLA2R1 or THSD7A), which induces damage to podocytes with subsequent urinary loss of plasma proteins. Complement-dependent and complementindependent injury mechanisms are likely to be involved. Depletion of autoantibody-producing B cells or elimination of pathogenic autoantibodies constitute potential antigen-specific treatments for MN. 


\section{CURRENT TREATMENTS FOR MN}

The clinical outcome in patients with $\mathrm{MN}$ is highly variable with about one-third of patients experiencing spontaneous remission within one year after diagnosis, whereas another 20-30\% develop end-stage renal disease within 10 years (25). The identification of patients with an unfavorable outcome, which would benefit from early immunosuppressive treatment, represents a major clinical challenge. Classical treatment regimens for $\mathrm{MN}$ include the use of steroids in combination with alkylating agents or calcineurin inhibitors (26-29). Recently, two large prospective clinical trials have investigated the use of rituximab in the treatment for $\mathrm{MN}$. The MENTOR trial compared rituximab with cyclosporine and found rituximab to be superior to cyclosporine in maintaining remission for up to 24 months (30). The RI-CYCLO trial found comparable remission rates with the use of rituximab and cyclophosphamide and no significant differences in the safety profiles of these medications (31).

The novel KDIGO guidelines define clusters of patients according to the risk of disease progression and loss of renal function. Categories comprise low risk, moderate risk, high risk, and very high risk, depending on proteinuria, serum albumin, estimated GFR (eGFR), and anti-PLA2R1 antibody levels (1). Patients with a low or moderate risk of disease progression are usually treated with optimal supportive care (e.g. antiproteinuric therapy with renin-angiotensin aldosterone system inhibition (RAAS) and blood pressure control) and monitored for 3-6 months. In case of worsening proteinuria, eGFR or antibody levels, patients should be evaluated for treatment with rituximab or calcineurin inhibitors. Patients with a high risk of disease progression should be treated with rituximab or cyclophosphamide plus steroids or a calcineurin inhibitor plus rituximab and patients with a very high risk should receive cyclophosphamide plus steroids (1).

While calcinerin inhibitors and cyclophosphamide are broad immunosuppressants, rituximab is targeting B cells expressing the surface marker CD20. Initially developed as a lymphoma treatment, it acts through different mechanisms of action: i) Antibody-dependent cellular cytotoxicity (ADCC) through either NK cells, monocytes or granulocytes (32-34) (ii) apoptosis of B cells through caspase 3 activation (35) and iii) complement-dependent cytotoxicity $(36,37)$.

In summary, the targets of autoimmunity in $\mathrm{MN}$ have been increasingly understood and therapies have shifted from broad immunosuppression using alkylating agents and calcineurin inhibitors towards a more pathogenesis-based treatment targeting autoantibody-producing B cells using rituximab. However, rituximab treatment may entail resistance towards apoptosis, ADCC, CDC and downregulation or loss of CD20 (38), which can decrease treatment efficacy. It also affects preexisting protective antibodies, reduces the body's ability to generate an immune response against foreign organisms, and greatly decreases the response to vaccination. These are undesired effects of B cell-targeted treatments, in particular in the setting of a worldwide pandemic (39), and may limit the use of agents such as rituximab in the treatment of antibodymediated diseases. Additionally, the increasing knowledge on specific antigens in $\mathrm{MN}$ principally enables antigen-specific treatment strategies, which would ideally target the immunological disease mechanisms while sparing protective immunity. Such antigen-specific therapies would have enormous potential to enhance specificity, efficacy and compatibility. Hence, there is a considerable gap between the increasing knowledge on the pathogenic role of autoantibodies and autoantigens in $\mathrm{MN}$ on the one side and the currently available treatments with limited specificity on the other side.

In the following, we will discuss two promising strategies that could be applied in the field of MN: The elimination of pathogenic antibodies through endogenous degradation systems and the elimination of autoreactive B cells through chimeric autoantibody receptor $\mathrm{T}$ cells (Figure 1).

\section{NO SWEEPING UNDER THE RUG: THE SWEEPING ANTIBODY TECHNOLOGY}

Physiologically, immunoglobulins (IgG) are constantly taken up by endothelial cells and shuttled to the sorting endosome. At $\mathrm{pH}$ 6 inside the sorting endosome IgG binds to the neonatal Fc receptor $(\mathrm{FcRn})$ and is transported to the cell surface. Now at $\mathrm{pH}$ 7.4 the IgG is released from the FcRn back into the circulation due to a reduced affinity at neutral $\mathrm{pH}$. This system prolongs the half-life of IgG in the circulation to approximately 30 days (40). Consequently, antibodies may also prolong the half-life of their target antigen by constant recirculation from endothelial cells back to the plasma.

Sweeping antibodies as potential therapeutics to remove soluble antigens from plasma were first described by Igawa et al. (41). Sweeping antibodies are engineered $\operatorname{IgG}$ that remove soluble antigens from the circulation, which is enabled by two distinct modifications: a pH-dependent binding to the antigen and an increased affinity of the antibody $\mathrm{Fc}$ part to an $\mathrm{Fc}$ receptor ( $\mathrm{FcR}$ ) (41). A pH-dependent antigen binding can be achieved by histidine mutagenesis, meaning that amino acids in the Fab region of the antibody are substituted for histidines. In the acidic environment of the sorting endosome, the protonated histidines lead to conformational changes in the Fab region of the sweeping antibody, which results in weakening of the binding to the antigen and finally dissociation of antibody and antigen. Enhanced immune complex uptake into the endosome is achieved by mutations in the Fc region, increasing the binding to either FcRn or FcyRIIB.

After injection, a sweeping antibody binds its target molecule in the circulation. The resulting immune complex is then taken up into endothelial cells by pinocytosis or FcR-mediated endocytosis. In the sorting endosome, the $\mathrm{pH}$ shifts from neutral to slightly acidic ( $\mathrm{pH} \mathrm{6)}$ and the antigen is released from the sweeping antibody. While the sweeping antibody bound by the FcRn - is shuttled to the cell surface and released there, the antigen is degraded in the lysosome. The enhanced affinity to the FcR allows efficient recirculation of the therapeutic sweeping antibody from endothelial cells to the plasma, which in turn leads to further removal of antigens from the circulation, creating the "sweeping" effect. Several different mutations have 
been described that enhance active internalization of antigenantibody complexes via FcRn, leading to efficient degradation of the antigen (42-44).

Sweeping can also occur through the Fc $\gamma$ RIIB (45). Fc $\gamma$ RIIB is the only inhibitory $\mathrm{Fc}$ receptor with an immunoreceptor-based inhibitory motif (ITIM) and normally has a very low affinity for $\operatorname{IgG}$ monomers (IgG1 $<\operatorname{IgG} 2 \mathrm{a}=\operatorname{IgG} 2 \mathrm{~b}<\operatorname{IgG} 3)$ (46). Fc $\gamma R$ IIB is, for example, expressed on B cells regulating their activation (47), and on myeloid-derived cells modulating endocytosis through clathrin-coated pits (48). Liver sinusoidal endothelial cells (LSECs) are scavenger cells specialized to clear blood from smaller immune complexes through pinocytosis (49). In mice, three quarters of all Fc $\gamma$ RIIB are expressed in the liver and $90 \%$ of liver Fc $\gamma$ RIIB is found on the surface of LSECs (50). Interestingly, Ganesan et al. could demonstrate that small immune complexes are cleared via FcyRIIB-mediated uptake into the liver (50). Binding to FcrRIIB can be dramatically enhanced by mutating the Fc part of the sweeping antibody, leading to efficient clearing of soluble antigens (51).

Recently, it could be demonstrated that the sweeping antibody principle can also be applied for the elimination of antigen-specific antibodies. Devanaboyina et al. (52) used therapeutic antibodies including fragments of either the myelin oligodendrocyte glycoprotein (MOG), an antigen in multiple sclerosis, or HER2, a tumor protein (52). The therapeutic antibodies specifically bound to anti-MOG and anti-HER2 antibodies, which lead to rapid clearance of the resulting immune complex in mice. In a follow-up study, the authors could demonstrate a therapeutic effect using similar constructs in a mouse model of multiple sclerosis (53).

The increasing knowledge on pathogenic autoantibodies in $\mathrm{MN}$ and their target antigens offers excellent conditions to apply the sweeping antibody concept also in this disease. Sweeping antibodies with the Fab region substituted for an antigen fragment could be generated and tested for their capacity to bind and eliminate specific autoantibodies. As virtually $100 \%$ of patients with PLA2R1-associated MN have antibodies against the most N-terminal domain (the cysteine-rich domain) of PLA2R1 (54-56), a sweeping antibody containing this part of PLA2R1 may be a promising candidate - yet therapeutic antibodies could be engineered for any $\mathrm{MN}$ antigen and tailored to the immune and epitope profile of each individual patient. After administration, the therapeutic sweeping antibodies bind their targets, the pathogenic autoantibodies, in the circulation. The resulting immune complex is then taken up by liver LSECs through enhanced affinity for FcyRIIB or by other endothelial cells via FcRn, resulting in lysosomal degradation of the pathogenic autoantibodies and potentially recirculation of the therapeutic sweeping antibody (Figure 2A). Fewer autoantibodies could bind their target antigen in the kidney, potentially leading to amelioration of disease activity. This can improve the course of MN without affecting parts of the immune system that are essential for the body's defense e.g. against infection. In summary, the elimination of pathogenic autoantibodies through endogenous degradation systems represents a promising therapeutic strategy for patients with MN.

\section{STRIKING THE EVIL AT ITS ROOTS: CHIMERIC AUTOANTIBODY RECEPTOR T CELLS}

Chimeric antigen receptor (CAR) $\mathrm{T}$ cells are a promising treatment for cancer, used with remarkable success for example in refractory or relapsed B cell lymphoma (57-59). To obtain such CAR T cells, peripheral blood mononuclear cells from the patient's blood are isolated and stimulated with interleukin 2 and anti-CD3 antibodies, leading to their proliferation. The $\mathrm{T}$ cells are transduced with a construct encoding for the CAR of interest, e.g. the antigen-binding domain of an anti-CD19 antibody fused to a transmembrane and several intracellular signaling domains such as $4-1 \mathrm{BB}$ and $\mathrm{CD} 3 \zeta$ (60). Upon transfusion back to the patient, the CAR T cells eliminate cells expressing the target antigen, in this case CD19, which is a marker of $\mathrm{B}$ cells. A huge advantage of this treatment is the generation of long-term memory CAR T cells, which offer the opportunity for constant elimination of newly emerging target cells without the need for repetitive dosing.

This strategy can also be applied for the treatment of antibodymediated autoimmune diseases, with one essential modification: the antigen-binding domain of a conventional CAR is replaced by a part of the autoantigen of interest, resulting in a chimeric autoantibody receptor (CAAR). A T cell expressing this CAAR (CAAR T cell) will bind to and eliminate $B$ cells that express the corresponding $\mathrm{B}$ cell receptor (BCR), a membrane-bound immunoglobulin matching the antibody produced by this particular cell clone. This approach was firstly tested in an animal model of pemphigus vulgaris (PV). T cells expressing a CAAR consisting of the PV autoantigen desmoglein 3 fused to CD137-CD3 $\zeta$ specifically eliminated anti-desmoglein 3 -specific autoreactive B cells (61). Moreover, the CAAR T cells erased their targets even in the presence of circulating anti-desmoglein 3 antibodies and did not show significant off target effects. In a follow-up study, the authors preclinically examined the pharmacodynamics and toxicity of this CAAR and showed that the desmoglein 3-CAAR $\mathrm{T}$ cells specifically deplete primary human desmoglein 3-specific B cells from PV patients and is effective in an active animal model of PV (62).

Applying the CAAR T cell strategy for the treatment of MN would be a pioneering approach. The antibody binding sites in the antigens PLA2R1 and THSD7A have been already characterized, in parts even down to the level of single antigen domains and smaller epitopes (54-56, 63-65). Given this knowledge, to achieve an optimal intermembrane distance of the immunologic synapse (the space between the CAAR T cell and the target $\mathrm{B}$ cell) and minimize potential off-target effects, it appears reasonable to fuse smaller fragments of PLA2R1 or the other $\mathrm{MN}$ antigens to the chimeric receptor (Figure 2B). In case of PLA2R1 and THSD7A the most N-terminal regions are considered as immunological hot spots, as most reactivity with patient autoantibodies is found in these areas $(56,63,64)$. Therefore, a CAAR containing only the N-terminal region of the respective autoantigen might be sufficient to eliminate a number of autoreactive B cells large enough to ameliorate 
A

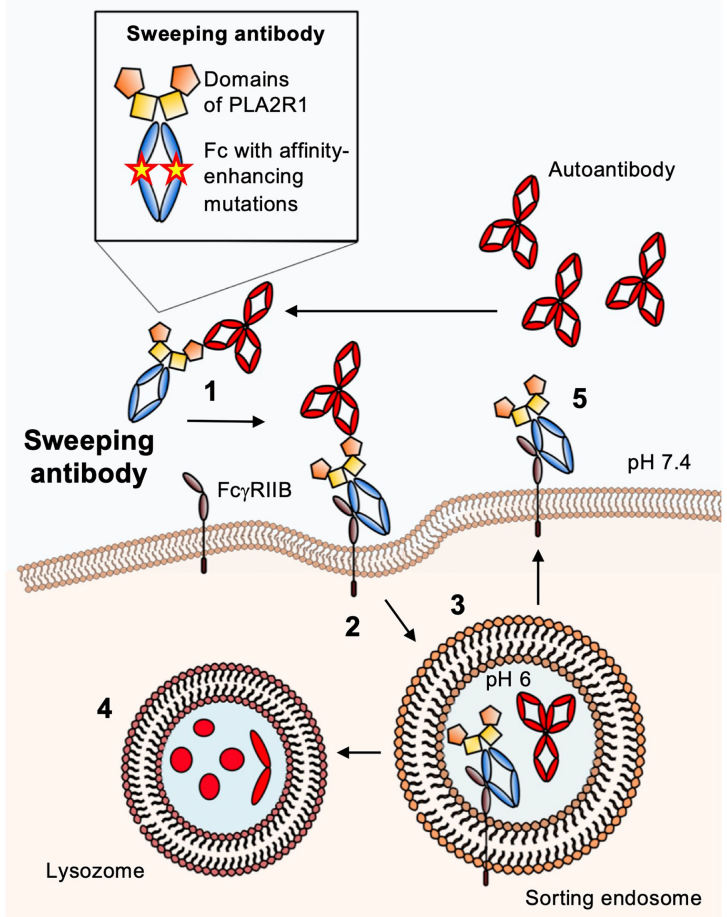

B

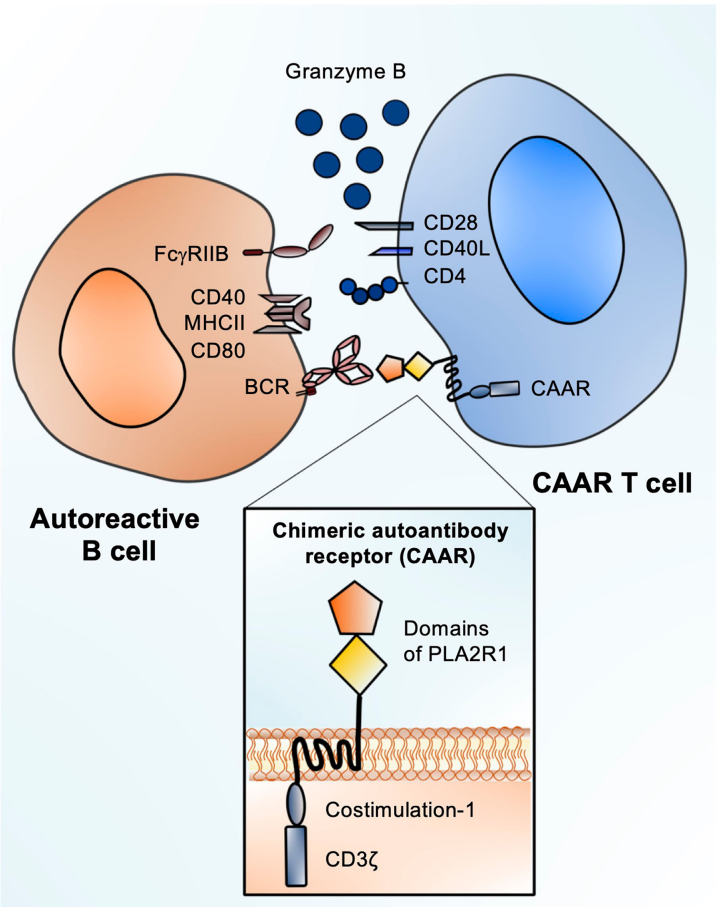

FIGURE 2 | Antigen-specific therapies suited for MN. (A) Schematic of the sweeping antibody principle with enhanced FcyRllB binding. 1. After injection, sweeping antibody and autoantibody bind in the circulation. 2. Scavenger cells like liver sinusoidal endothelial cells (LSECs) that express FcyRIIIB bind the circulating immune complex $(\mathrm{IC})$ and internalize it through pinocytosis. 3. Due to a pH shift from neutral to $\mathrm{pH} 6$ inside the sorting endosome, the autoantibody is released from the ICreceptor complex. 4. The autoantibody is degraded inside the lysosome. 5. The Fc receptor-bound sweeping antibody is returned to the surface and can bind new circulating autoantibodies causing the "sweeping" effect. Magnified: structure of a PLA2R1 sweeping antibody: The Fab part is substituted for the most N-terminal domains of PLA2R1 (cysteine-rich and fibronectin type II) to create specificity for anti-PLA2R1 autoantibodies. Mutations in the Fc part of the sweeping antibody enhance the affinity towards FcyRIIB. (B) Schematic of chimeric autoantibody receptor (CAAR) T cell principle. The CAAR comprises fragments of the target antigen (in this case the cysteine-rich and fibronectin type II domains of PLA2R1), a transmembrane domain, and several intracellular signaling domains. The CAAR enables binding to a B cell, which expresses the corresponding B cell receptor (BCR), a membrane-anchored IgG corresponding to the autoantibody that is produced by the B cell. CAAR-mediated binding of the T cell to the pathogenic B cell leads to release of granzyme B, which eliminates the target B cell. Magnified: structure of a second generation CAAR. It includes the autoantibody receptor as a ectodomain, here the most N-terminal domains of PLA2R, a transmembrane part and an endodomain with co-stimulation module and the $\mathrm{CD} 3 \zeta$ with three immunoreceptor tyrosine-based activation motifs (ITAMs). The co-stimulatory domain improves the half-life in vivo, proliferation and cytotoxity of the CAAR T cell.

disease. It would also be possible to perform an antibody mapping first, e.g. using domain-specific ELISAs, and tailor the CAAR strategy to the individual epitope profile.

Although the CAR $\mathrm{T}$ cell therapy has revolutionized the treatment of malignancies, it has several potential flaws. First, the manufacturing of personalized CAR T cells is very complex, time-consuming and expensive. Second, CAR T cell therapy could involve serious adverse effects, such as the cytokine release syndrome (CRS), caused by the activation of CAR T cells and their production of proinflammatory cytokines $(66,67)$, or neurotoxicity, which often accompanies CRS, possibly due to cerebral endothelial dysfunction (68). Third, it is questionable whether the generation of memory $\mathrm{T}$ cells is always desirable in light of many patients achieving full remission of disease after some time.

The generation of CAR NK cells represents an alternative strategy to overcome some of these undesired effects. Due to their limited lifespan, CAR NK cells show a relatively low toxicity towards normal tissue of the recipient (69). They offer the possibility of "off the shelf" therapy as they can be obtained from peripheral blood mononuclear cells of healthy donors, umbilical cord blood, induced pluripotent stem cells, and even NK92 cell lines (70). Currently, most of the CAR NK constructs derive from CAR T cell approaches, but there are attempts to design also CARs tailored specifically for NK cells (71). To date, CAR NK cell therapy seems to be a safe additional approach for cancer therapy, with several clinical trials running $(72,73)$. In conclusion, CAAR T cell therapy and, alternatively, the safer and likely more cost-efficient and easier to manufacture CAAR NK cell therapy represent an elegant and promising therapeutic strategy for patients with $\mathrm{MN}$.

Notably, is also possible to approach $\mathrm{T}$ cell therapy from the opposite site, by regaining immune tolerance. To achieve this, the function of one key player of immune tolerance has to be 
modified: the so called regulatory T cells or Tregs. About 5-7\% of all CD4+ T cells in the human body are Tregs. The identity and function of Tregs are characterized by the expression of various markers such as the cytotoxic T lymphocyte-associated protein- 4 (CTLA-4), the interleukin 2 receptor subunit $\alpha$ (CD25), the transcription-maintaining factor STAT5, and the forkhead box P3 (FOXP3). FOXP3 has a key function for the maintenance of immune tolerance (74).

Tregs can be transduced with so called BARs (chimeric B celltargeting antibody receptors) containing an extracellular domain consisting of the immunodominant parts of the antigen, which means they are basically comparable to CAARs on cytotoxic T cells. Instead of killing the B- cell upon binding, such BAR Tregs suppress antigen-specific $B$ cells directly without affecting the $T$ cell response (75).

\section{CONCLUSION}

$\mathrm{MN}$ is an antibody-mediated autoimmune disease and several autoantigens have been identified over the past years. The direct pathogenicity of the involved autoantibodies has either been shown or is strongly suspected $(20,22)$, and treatment strategies have shifted towards targeting of B cells $(30,31,76)$. In light of these developments, the establishment of antigen-specific treatments represents the consequential continuation of $\mathrm{MN}$ therapy. We are aware that the therapeutic concepts discussed in this article have not been tested in $\mathrm{MN}$, not even at an experimental level. However, future research should take into account such potential strategies, particularly as antigen-specific animal models become more and more available $(22,77)$. Clearly, the possible adverse effects of such treatments should not be overlooked, but there is a realistic chance that they would not be as severe as the ones of currently used therapeutics. Especially in case of CAR T cells, huge efforts are made to reduce side effects and make them more controllable, e.g. through transient transduction, suicide genes or elimination markers (78).

The actual charm of the two treatment approaches that we presented here is the option to combine and apply them as a therapeutic package tailored for the individual patient. As an example, one could imagine the following procedure: After

\section{REFERENCES}

1. Kidney Disease: Improving Global Outcomes Glomerular Diseases Work Group. KDIGO 2021 Clinical Practice Guideline for the Management of Glomerular Diseases. Kidney Int (2021) 100(4S):S1-276. doi: 10.1016/ j.kint.2021.05.021

2. Jones DB. Nephrotic Glomerulonephritis. Am J Pathol (1957) 33(2):313-29.

3. Debiec H, Guigonis V, Mougenot B, Decobert F, Haymann JP, Bensman A, et al. Antenatal Membranous Glomerulonephritis Due to Anti-Neutral Endopeptidase Antibodies. N Engl J Med (2002) 346(26):2053-60. doi: 10.1056/NEJMoa012895

4. Beck LH Jr, Bonegio RG, Lambeau G, Beck DM, Powell DW, Cummins TD, et al. M-Type Phospholipase A2 Receptor as Target Antigen in Idiopathic Membranous Nephropathy. N Engl J Med (2009) 361(1):11-21. doi: 10.1056/ NEJMoa0810457

5. Tomas NM, Beck LH Jr, Meyer-Schwesinger C, Seitz-Polski B, Ma H, Zahner G, et al. Thrombospondin Type-1 Domain-Containing 7A in Idiopathic confirming the diagnosis of PLA2R1-associated MN by kidney biopsy, the antibody profile is analyzed using a domain-specific ELISA, revealing reactivity with the cysteine-rich domain. Subsequently, sweeping antibodies containing the cysteine-rich domain are applied to eliminate the circulating autoantibodies. This acutely reduces binding of pathogenic antibodies at the glomerular filtration barrier and additionally paves the way for CAAR T or NK cells carrying a CAAR which contains the cysteine-rich domain. The CAAR T or NK cells thus eliminate autoreactive $\mathrm{B}$ cells, which prevents further production of pathogenic antibodies. Without previous clearance of antibodies, CAAR cells may in fact be neutralized by the circulating antibodies binding to the CAAR, potentially making them ineffective in eliminating autoreactive B cells. As an alternative or additive strategy, PLA2R1-specific immune tolerance could be restored by suppression of autoreactive B cells using Tregs expressing a BAR that contains the cysteinerich domain.

In summary, the increasing knowledge about the targets of autoimmunity in $\mathrm{MN}$ offers a huge potential for the application of antigen-specific treatment strategies, which would ideally spare protective immunity.

\section{AUTHOR CONTRIBUTIONS}

SK and LS contributed equally to this review. NT conceptualized the work. All authors discussed the concept and revised the manuscript. All authors approved the final version of the manuscript.

\section{FUNDING}

This work was funded by the Deutsche Forschungsgemeinschaft as part of the Emmy Noether Programme "Molecular Mechanisms of Membranous Nephropathy" (TO10-13) to NT and as part of the Sonderforschungsbereich 1192 to NT (project B2). This work was additionally supported by the Deutsche Forschungsgemeinschaft (DFG) as part of the grant ZA163/12-1 to GZ.

Membranous Nephropathy. N Engl J Med (2014) 371(24):2277-87. doi: 10.1056/NEJMoa1409354

6. Sethi S, Debiec H, Madden B, Charlesworth MC, Morelle J, Gross L, et al. Neural Epidermal Growth Factor-Like 1protein (NELL-1) Associated Membranous Nephropathy. Kidney Int (2020) 97(1):163-74. doi: 10.1016/ j.kint.2019.09.014

7. Sethi S, Debiec H, Madden B, Vivarelli M, Charlesworth MC, Ravindran A, et al. Semaphorin 3B-Associated Membranous Nephropathy is a Distinct Type of Disease Predominantly Present in Pediatric Patients. Kidney Int (2020) 98(5):1253-64. doi: 10.1016/j.kint.2020.05.030

8. Sethi S, Madden B, Debiec H, Morelle J, Charlesworth MC, Gross L, et al. Protocadherin 7-Associated Membranous Nephropathy. J Am Soc Nephrol (2021) 32(5):1249-61. doi: 10.1681/ASN.2020081165

9. Caza TN, Hassen SI, Kuperman M, Sharma SG, Dvanajscak Z, Arthur J, et al. Neural Cell Adhesion Molecule 1 is a Novel Autoantigen in Membranous Lupus Nephritis. Kidney Int (2021) 100(1):171-81. doi: 10.1016/j.kint. 2020.09.016 
10. Al-Rabadi LF, Caza T, Trivin-Avillach C, Rodan AR, Andeen N, Hayashi N, et al. Serine Protease HTRA1 as a Novel Target Antigen in Primary Membranous Nephropathy. J Am Soc Nephrol (2021) 32(7):1666-81. doi: 10.1681/ASN.2020101395

11. Stanescu HC, Arcos-Burgos M, Medlar A, Bockenhauer D, Kottgen A, Dragomirescu L, et al. Risk HLA-DQA1 and PLA(2)R1 Alleles in Idiopathic Membranous Nephropathy. N Engl J Med (2011) 364(7):616-26. doi: 10.1056/ NEJMoa1009742

12. Xu X, Wang G, Chen N, Lu T, Nie S, Xu G, et al. Long-Term Exposure to Air Pollution and Increased Risk of Membranous Nephropathy in China. J Am Soc Nephrol (2016) 27(12):3739-46. doi: 10.1681/ASN.2016010093

13. Hoxha E, Wiech T, Stahl PR, Zahner G, Tomas NM, Meyer-Schwesinger C, et al. A Mechanism for Cancer-Associated Membranous Nephropathy. N Engl J Med (2016) 374(20):1995-6. doi: 10.1056/NEJMc1511702

14. Hoxha E, Beck LH Jr, Wiech T, Tomas NM, Probst C, Mindorf S, et al. An Indirect Immunofluorescence Method Facilitates Detection of Thrombospondin Type 1 Domain-Containing 7a-Specific Antibodies in Membranous Nephropathy. J Am Soc Nephrol (2017) 28(2):520-31. doi: 10.1681/ASN.2016010050

15. Stahl PR, Hoxha E, Wiech T, Schroder C, Simon R, Stahl RA. THSD7A Expression in Human Cancer. Genes Chromosomes Cancer (2017) 56(4):31427. doi: $10.1002 /$ gcc. 22440

16. Cremoni M, Brglez V, Perez S, Decoupigny F, Zorzi K, Andreani M, et al. Th17-Immune Response in Patients With Membranous Nephropathy Is Associated With Thrombosis and Relapses. Front Immunol (2020) 11:574997. doi: 10.3389/fimmu.2020.574997

17. Motavalli R, Etemadi J, Soltani-Zangbar MS, Ardalan MR, Kahroba H, Roshangar L, et al. Altered Th17/Treg Ratio as a Possible Mechanism in Pathogenesis of Idiopathic Membranous Nephropathy. Cytokine (2021) 141:155452. doi: 10.1016/j.cyto.2021.155452

18. Rosenzwajg M, Languille E, Debiec H, Hygino J, Dahan K, Simon T, et al. Band T-Cell Subpopulations in Patients With Severe Idiopathic Membranous Nephropathy may Predict an Early Response to Rituximab. Kidney Int (2017) 92(1):227-37. doi: 10.1016/j.kint.2017.01.012

19. Tomas NM, Huber TB, Hoxha E. Perspectives in Membranous Nephropathy. Cell Tissue Res (2021) 385(2):405-22. doi: 10.1007/s00441-021-03429-4

20. Tomas NM, Hoxha E, Reinicke AT, Fester L, Helmchen U, Gerth J, et al. Autoantibodies Against Thrombospondin Type 1 Domain-Containing 7A Induce Membranous Nephropathy. J Clin Invest (2016) 126(7):2519-32. doi: $10.1172 / J C I 85265$

21. Hoxha E, Thiele I, Zahner G, Panzer U, Harendza S, Stahl RA. Phospholipase A2 Receptor Autoantibodies and Clinical Outcome in Patients With Primary Membranous Nephropathy. J Am Soc Nephrol (2014) 25(6):1357-66. doi: 10.1681/ASN.2013040430

22. Meyer-Schwesinger C, Tomas NM, Dehde S, Seifert L, Hermans-Borgmeyer I, Wiech T, et al. A Novel Mouse Model of Phospholipase A2 Receptor 1Associated Membranous Nephropathy Mimics Podocyte Injury in Patients. Kidney Int (2020) 97(5):913-9. doi: 10.1016/j.kint.2019.10.022

23. Debiec H, Lefeu F, Kemper MJ, Niaudet P, Deschenes G, Remuzzi G, et al. Early-Childhood Membranous Nephropathy Due to Cationic Bovine Serum Albumin. N Engl J Med (2011) 364(22):2101-10. doi: 10.1056/ NEJMoa1013792

24. Ronco P, Debiec H. Pathophysiological Advances in Membranous Nephropathy: Time for a Shift in Patient's Care. Lancet (9981) 2015:1983-92:385. doi: 10.1016/ S0140-6736(15)60731-0

25. Cattran D. Management of Membranous Nephropathy: When and What for Treatment. J Am Soc Nephrol (2005) 16(5):1188-94. doi: 10.1681/ASN.2005010028

26. Ponticelli C, Zucchelli P, Imbasciati E, Cagnoli L, Pozzi C, Passerini P, et al. Controlled Trial of Methylprednisolone and Chlorambucil in Idiopathic Membranous Nephropathy. N Engl J Med (1984) 310(15):946-50. doi: 10.1056/NEJM198404123101503

27. Ponticelli C, Zucchelli P, Passerini P, Cesana B, Locatelli F, Pasquali S, et al. A 10-Year Follow-Up of a Randomized Study With Methylprednisolone and Chlorambucil in Membranous Nephropathy. Kidney Int (1995) 48(5):1600-4. doi: 10.1038/ki.1995.453

28. Cattran DC, Greenwood C, Ritchie S, Bernstein K, Churchill DN, Clark WF, et al. A Controlled Trial of Cyclosporine in Patients With Progressive Membranous Nephropathy. Canadian Glomerulonephritis Study Group. Kidney Int (1995) 47(4):1130-5. doi: 10.1038/ki.1995.161
29. Cattran DC, Appel GB, Hebert LA, Hunsicker LG, Pohl MA, Hoy WE, et al. Cyclosporine in Patients With Steroid-Resistant Membranous Nephropathy: A Randomized Trial. Kidney Int (2001) 59(4):1484-90. doi: 10.1046/j.15231755.2001.0590041484.x

30. Fervenza FC, Appel GB, Barbour SJ, Rovin BH, Lafayette RA, Aslam N, et al. Rituximab or Cyclosporine in the Treatment of Membranous Nephropathy. $N$ Engl J Med (2019) 381(1):36-46. doi: 10.1056/NEJMoa1814427

31. Scolari F, Delbarba E, Santoro D, Gesualdo L, Pani A, Dallera N, et al. Rituximab or Cyclophosphamide in the Treatment of Membranous Nephropathy: The RI-CYCLO Randomized Trial. J Am Soc Nephrol (2021) 32(4):972-82. doi: 10.1681/ASN.2020071091

32. Koene HR, Kleijer M, Algra J, Roos D, von dem Borne AE, de Haas M. Fc gammaRIIIa-158v/F Polymorphism Influences the Binding of IgG by Natural Killer Cell Fc gammaRIIIa, Independently of the Fc gammaRIIIa-481/R/H Phenotype. Blood (1997) 90(3):1109-14. doi: 10.1182/blood.V90.3.1109

33. Wu J, Edberg JC, Redecha PB, Bansal V, Guyre PM, Coleman K, et al. A Novel Polymorphism of FcgammaRIIIa (CD16) Alters Receptor Function and Predisposes to Autoimmune Disease. J Clin Invest (1997) 100(5):1059-70. doi: 10.1172/JCI119616

34. Clynes RA, Towers TL, Presta LG, Ravetch JV. Inhibitory Fc Receptors Modulate In Vivo Cytotoxicity Against Tumor Targets. Nat Med (2000) 6 (4):443-6. doi: 10.1038/74704

35. Byrd JC, Kitada S, Flinn IW, Aron JL, Pearson M, Lucas D, et al. The Mechanism of Tumor Cell Clearance by Rituximab In Vivo in Patients With B-Cell Chronic Lymphocytic Leukemia: Evidence of Caspase Activation and Apoptosis Induction. Blood (2002) 99(3):1038-43. doi: 10.1182/ blood.V99.3.1038

36. Kumar A, Planchais C, Fronzes R, Mouquet H, Reyes N. Binding Mechanisms of Therapeutic Antibodies to Human CD20. Science (2020) 369(6505):793-9. doi: $10.1126 /$ science.abb8008

37. Rouge L, Chiang N, Steffek M, Kugel C, Croll TI, Tam C, et al. Structure of CD20 in Complex With the Therapeutic Monoclonal Antibody Rituximab. Science (2020) 367(6483):1224-30. doi: 10.1126/science.aaz9356

38. Rezvani AR, Maloney DG. Rituximab Resistance. Best Pract Res Clin Haematol (2011) 24(2):203-16. doi: 10.1016/j.beha.2011.02.009

39. Mehta P, Porter JC, Chambers RC, Isenberg DA, Reddy V. B-Cell Depletion With Rituximab in the COVID-19 Pandemic: Where do We Stand? Lancet Rheumatol (2020) 2(10):e589-90. doi: 10.1016/S2665-9913 (20)30270-8

40. Sand KM, Bern M, Nilsen J, Noordzij HT, Sandlie I, Andersen JT. Unraveling the Interaction Between FcRn and Albumin: Opportunities for Design of Albumin-Based Therapeutics. Front Immunol (2014) 5:682. doi: 10.3389/ fimmu.2014.00682

41. Igawa T, Maeda A, Haraya K, Tachibana T, Iwayanagi Y, Mimoto F, et al. Engineered Monoclonal Antibody With Novel Antigen-Sweeping Activity In Vivo. PloS One (2013) 8(5):e63236. doi: 10.1371/journal.pone.0063236

42. Vaccaro C, Zhou J, Ober RJ, Ward ES. Engineering the Fc Region of Immunoglobulin G to Modulate In Vivo Antibody Levels. Nat Biotechnol (2005) 23(10):1283-8. doi: 10.1038/nbt1143

43. Gan Z, Ram S, Vaccaro C, Ober RJ, Ward ES. Analyses of the Recycling Receptor, FcRn, in Live Cells Reveal Novel Pathways for Lysosomal Delivery. Traffic (2009) 10(5):600-14. doi: 10.1111/j.1600-0854.2009.00887.x

44. Igawa T, Haraya K, Hattori K. Sweeping Antibody as a Novel Therapeutic Antibody Modality Capable of Eliminating Soluble Antigens From Circulation. Immunol Rev (2016) 270(1):132-51. doi: 10.1111/imr.12392

45. Chu SY, Horton HM, Pong E, Leung IW, Chen H, Nguyen DH, et al. Reduction of Total IgE by Targeted Coengagement of IgE B-Cell Receptor and FcgammaRIIb With Fc-Engineered Antibody. J Allergy Clin Immunol (2012) 129(4):1102-15. doi: 10.1016/j.jaci.2011.11.029

46. Vidarsson G, Dekkers G, Rispens T. IgG Subclasses and Allotypes: From Structure to Effector Functions. Front Immunol (2014) 5:520. doi: 10.3389/ fimmu. 2014.00520

47. Joshi T, Ganesan LP, Cao X, Tridandapani S. Molecular Analysis of Expression and Function of Hfcgammariibl and B2 Isoforms in Myeloid Cells. Mol Immunol (2006) 43(7):839-50. doi: 10.1016/j.molimm.2005.06.037

48. Miettinen HM, Rose JK, Mellman I. Fc Receptor Isoforms Exhibit Distinct Abilities for Coated Pit Localization as a Result of Cytoplasmic Domain Heterogeneity. Cell (1989) 58(2):317-27. doi: 10.1016/0092-8674(89)90846-5 
49. Skogh T, Blomhoff R, Eskild W, Berg T. Hepatic Uptake of Circulating IgG Immune Complexes. Immunology (1985) 55(4):585-94.

50. Ganesan LP, Kim J, Wu Y, Mohanty S, Phillips GS, Birmingham DJ, et al. FcgammaRIIb on Liver Sinusoidal Endothelium Clears Small Immune Complexes. J Immunol (2012) 189(10):4981-8. doi: 10.4049/ jimmunol.1202017

51. Iwayanagi Y, Igawa T, Maeda A, Haraya K, Wada NA, Shibahara N, et al. Inhibitory FcgammaRIIb-Mediated Soluble Antigen Clearance From Plasma by a pH-Dependent Antigen-Binding Antibody and Its Enhancement by Fc Engineering. J Immunol (2015) 195(7):3198-205. doi: 10.4049/ jimmunol.1401470

52. Devanaboyina SC, Khare P, Challa DK, Ober RJ, Ward ES. Engineered Clearing Agents for the Selective Depletion of Antigen-Specific Antibodies. Nat Commun (2017) 8:15314. doi: 10.1038/ncomms15314

53. Sun W, Khare P, Wang X, Challa DK, Greenberg BM, Ober RJ, et al. Selective Depletion of Antigen-Specific Antibodies for the Treatment of Demyelinating Disease. Mol Ther (2021) 29(3):1312-23. doi: 10.1016/j.ymthe.2020.11.017

54. Kao L, Lam V, Waldman M, Glassock RJ, Zhu Q. Identification of the Immunodominant Epitope Region in Phospholipase A2 ReceptorMediating Autoantibody Binding in Idiopathic Membranous Nephropathy. J Am Soc Nephrol (2015) 26(2):291-301. doi: 10.1681/ASN.2013121315

55. Fresquet M, Jowitt TA, Gummadova J, Collins R, O'Cualain R, McKenzie EA, et al. Identification of a Major Epitope Recognized by PLA2R Autoantibodies in Primary Membranous Nephropathy. J Am Soc Nephrol (2015) 26(2):30213. doi: $10.1681 /$ ASN.2014050502

56. Seitz-Polski B, Dolla G, Payre C, Girard CA, Polidori J, Zorzi K, et al. Epitope Spreading of Autoantibody Response to PLA2R Associates With Poor Prognosis in Membranous Nephropathy. J Am Soc Nephrol (2016) 27 (5):1517-33. doi: 10.1681/ASN.2014111061

57. Park JH, Riviere I, Gonen M, Wang X, Senechal B, Curran KJ, et al. LongTerm Follow-Up of CD19 CAR Therapy in Acute Lymphoblastic Leukemia. N Engl J Med (2018) 378(5):449-59. doi: 10.1056/NEJMoa1709919

58. Maude SL, Laetsch TW, Buechner J, Rives S, Boyer M, Bittencourt H, et al. Tisagenlecleucel in Children and Young Adults With B-Cell Lymphoblastic Leukemia. N Engl J Med (2018) 378(5):439-48. doi: 10.1056/NEJMoa1709866

59. Schuster SJ, Bishop MR, Tam CS, Waller EK, Borchmann P, McGuirk JP, et al. Tisagenlecleucel in Adult Relapsed or Refractory Diffuse Large B-Cell Lymphoma. N Engl J Med (2019) 380(1):45-56. doi: 10.1056/NEJMoa1804980

60. June CH, Sadelain M. Chimeric Antigen Receptor Therapy. N Engl J Med (2018) 379(1):64-73. doi: 10.1056/NEJMra1706169

61. Ellebrecht CT, Bhoj VG, Nace A, Choi EJ, Mao X, Cho MJ, et al. Reengineering Chimeric Antigen Receptor T Cells for Targeted Therapy of Autoimmune Disease. Science (2016) 353(6295):179-84. doi: 10.1126/ science.aaf6756

62. Lee J, Lundgren DK, Mao X, Manfredo-Vieira S, Nunez-Cruz S, Williams EF, et al. Antigen-Specific B Cell Depletion for Precision Therapy of Mucosal Pemphigus Vulgaris. J Clin Invest (2020) 130(12):6317-24. doi: 10.1172/JC1138416

63. Reinhard L, Zahner G, Menzel S, Koch-Nolte F, Stahl RAK, Hoxha E. Clinical Relevance of Domain-Specific Phospholipase A2 Receptor 1 Antibody Levels in Patients With Membranous Nephropathy. J Am Soc Nephrol (2020) 31 (1):197-207. doi: 10.1681/ASN.2019030273

64. Seifert L, Hoxha E, Eichhoff AM, Zahner G, Dehde S, Reinhard L, et al. The Most N-Terminal Region of THSD7A Is the Predominant Target for Autoimmunity in THSD7A-Associated Membranous Nephropathy. J Am Soc Nephrol (2018) 29 (5):1536-48. doi: 10.1681/ASN.2017070805

65. Stoddard SV, Welsh CL, Palopoli MM, Stoddard SD, Aramandla MP, Patel RM, et al. Structure and Function Insights Garnered From in Silico Modeling of the Thrombospondin Type-1 Domain-Containing 7A Antigen. Proteins (2019) 87(2):136-45. doi: 10.1002/prot.25640

66. Teachey DT, Lacey SF, Shaw PA, Melenhorst JJ, Maude SL, Frey N, et al. Identification of Predictive Biomarkers for Cytokine Release Syndrome After Chimeric Antigen Receptor T-Cell Therapy for Acute Lymphoblastic
Leukemia. Cancer Discov (2016) 6(6):664-79. doi: 10.1158/2159-8290.CD16-0040

67. Frey N, Porter D. Cytokine Release Syndrome With Chimeric Antigen Receptor T Cell Therapy. Biol Blood Marrow Transplant (2019) 25(4):e1237. doi: 10.1016/j.bbmt.2018.12.756

68. Gust J, Hay KA, Hanafi LA, Li D, Myerson D, Gonzalez-Cuyar LF, et al. Endothelial Activation and Blood-Brain Barrier Disruption in Neurotoxicity After Adoptive Immunotherapy With CD19 CAR-T Cells. Cancer Discov (2017) 7(12):1404-19. doi: 10.1158/2159-8290.CD-17-0698

69. Tang X, Yang L, Li Z, Nalin AP, Dai H, Xu T, et al. First-In-Man Clinical Trial of CAR NK-92 Cells: Safety Test of CD33-CAR NK-92 Cells in Patients With Relapsed and Refractory Acute Myeloid Leukemia. Am J Cancer Res (2018) 8 (6):1083-9.

70. Shimasaki N, Jain A, Campana D. NK Cells for Cancer Immunotherapy. Nat Rev Drug Discov (2020) 19(3):200-18. doi: 10.1038/s41573-019-0052-1

71. Kotanides H, Sattler RM, Lebron MB, Carpenito C, Shen J, Li J, et al. Characterization of 7A5: A Human CD137 (4-1bb) Receptor Binding Monoclonal Antibody With Differential Agonist Properties That Promotes Antitumor Immunity. Mol Cancer Ther (2020) 19(4):988-98. doi: 10.1158/ 1535-7163.MCT-19-0893

72. Becker PS, Suck G, Nowakowska P, Ullrich E, Seifried E, Bader P, et al. Selection and Expansion of Natural Killer Cells for NK Cell-Based Immunotherapy. Cancer Immunol Immunother (2016) 65(4):477-84. doi: 10.1007/s00262-016-1792-y

73. Marofi F, Al-Awad AS, Sulaiman Rahman H, Markov A, Abdelbasset WK, Ivanovna Enina Y, et al. CAR-NK Cell: A New Paradigm in Tumor Immunotherapy. Front Oncol (2021) 11:673276. doi: 10.3389/ fonc.2021.673276

74. Corthay A. How do Regulatory T Cells Work? Scand J Immunol (2009) 70 (4):326-36. doi: 10.1111/j.1365-3083.2009.02308.x

75. Zhang AH, Yoon J, Kim YC, Scott DW. Targeting Antigen-Specific B Cells Using Antigen-Expressing Transduced Regulatory T Cells. J Immunol (2018) 201(5):1434-41. doi: 10.4049/jimmunol.1701800

76. Dahan K, Debiec H, Plaisier E, Cachanado M, Rousseau A, Wakselman L, et al. Rituximab for Severe Membranous Nephropathy: A 6-Month Trial With Extended Follow-Up. J Am Soc Nephrol (2017) 28(1):348-58. doi: 10.1681/ ASN.2016040449

77. Tomas NM, Meyer-Schwesinger C, von Spiegel H, Kotb AM, Zahner G, Hoxha E, et al. A Heterologous Model of Thrombospondin Type 1 DomainContaining 7a-Associated Membranous Nephropathy. J Am Soc Nephrol (2017) 28(11):3262-77. doi: 10.1681/ASN.2017010030

78. Brandt LJB, Barnkob MB, Michaels YS, Heiselberg J, Barington T. Emerging Approaches for Regulation and Control of CAR T Cells: A Mini Review. Front Immunol (2020) 11:326. doi: 10.3389/fimmu.2020.00326

Conflict of Interest: The authors declare that the research was conducted in the absence of any commercial or financial relationships that could be construed as a potential conflict of interest.

Publisher's Note: All claims expressed in this article are solely those of the authors and do not necessarily represent those of their affiliated organizations, or those of the publisher, the editors and the reviewers. Any product that may be evaluated in this article, or claim that may be made by its manufacturer, is not guaranteed or endorsed by the publisher.

Copyright $\odot 2022$ Köllner, Seifert, Zahner and Tomas. This is an open-access article distributed under the terms of the Creative Commons Attribution License (CC BY). The use, distribution or reproduction in other forums is permitted, provided the original author(s) and the copyright owner(s) are credited and that the original publication in this journal is cited, in accordance with accepted academic practice. No use, distribution or reproduction is permitted which does not comply with these terms. 